The Geneva Papers on Risk and Insurance, 21 (No. 81, October 1996) 469-477

\title{
The Role of the Fourth Pillar in the Redesign of Social Security
}

\author{
by Yung-Ping Chen*
}

\begin{abstract}
Social security programs are under intense criticism around the world ; increasingly, privatization is proposed as a solution. However, neither the public nor the private approach is problem-free. The choice may not be between public and private approaches but a combination of the two. The paper argues for creating a self-sustaining social security to serve as a stable foundation for some basic level of retirement income. In addition, after pointing out the importance of social security, the paper advocates strengthening the potential of employment as an additional source of income security.
\end{abstract}

\section{Introduction}

A recent book on reforming social security in China (Chow, 1987) reminds one of a government report that concluded: "Because of the rising volume of retirement cases over the years, it is our recommendation that a one-third reduction in pension benefits be instituted at the earliest opportune time..." Does that sound familiar? In fact, it was written more than 2,000 years ago in China during the Han dynasty (206 B.C. to 220 A.D.). At that time, only high government officials were granted pensions, and retirement eligibility began at age 70 , the same age as for the initial German social insurance retirement system enacted under Chancellor Otto von Bismarck in 1889. ${ }^{1}$

The economics and demography of financing retirement transcend geography and ideology. In the United States, both the Republican-dominated Congress and the Democratic President advocate, though to different degrees, cuts in Medicare and Medicaid and the reform of welfare programs. Similar discussions are gaining prominence in Latin America, Eastern and Central Europe, the former Soviet Union, and countries of the Organisation

* Yung-Ping Chen, Ph.D., is the Frank J. Manning Eminent Scolar's Chair in Gerontology at the University of Massachusetts Boston, USA, 02125-3393. A founding member of the National Academy of Social Insurance, he served on the Panel of Actuaries and Economists of the 1979 Advisory Council on Social Security. The author acknowledges substantive and editorial suggestions from Stephen C. Goss, Robert J. Myers, Francis P. King, Sara E. Rix, Al Duncker, Dana H. Murphy, Phoebe Liebig, Jill Norton, and anonymous referees.

1 Yung-Ping Chen, Time to Restructure Social Security, 30 (3) Gerontologist $422-4$ (1990). 
for Economic Cooperation and Development. Even Scandinavia, the mecca of social programs for the elderly, is not immune. In 1994, Sweden's opposition Social Democratic Party ran in the national election on a platform of raising taxes and cutting both social and defense spending in order to reduce the country's bulging budget deficits and massive national debt. This center-left political party, which had been responsible for building one of the world's most advanced welfare states, managed to win on that platform. Almost everywhere, in industrialized and developing countries alike, the same demanding question is asked: Which is a better way to provide for the older population now and in the future: the public or the private approach?

This article summarizes the World Bank's recent criticisms of social security programs and its proposal for a multipillar system of welfare payments and savings. Next, the article addresses important issues about privatization and the major reasons for the financial problems of social security programs. Then, the article illustrates how an existing social security plan may be redesigned into a self-sustaining and financially stable program. Noting the importance of social security, the article argues for strengthening the potential of part-time employment as an additional source of income in old age.

\section{Social security criticized}

Existing systems of social security are being scrutinized and criticized. A leading example is a 1994 World Bank report that has generated both interest and controversy. The report concluded that the problems with most publicly funded pay-as-you-go pension systems (the World Bank's term for social security) are :

(1) high payroll-tax rates (payroll tax rates for pensions are already over 25 percent in Egypt, Hungary, Russia, Brazil, and Italy);

(2) evasion and labor market distortions (in many Latin America countries, over 40 percent of the labor force works in the informal sector);

(3) early retirement (in Hungary, the average retirement age is 54 and in Turkey many people retire before age 50 or even age 40$)$;

(4) misallocation of public resources (in 1990, Austria, Italy, and Uruguay spent more than one-third of their public budgets on pensions);

(5) lost opportunities to increase savings (many countries believe that they have inadequate saving and this hampers growth);

(6) perverse redistribution to upper-income groups (in the early years of public plans, highincome groups have benefited most); and

(7) positive lifetime transfers to early cohorts and losses to their children (generally, covered workers retiring in the first 20 to 30 years of the plan get back much more than they contributed, but their children and grandchildren get back less than they paid in and receive lower rates of return than could have been earned elsewhere) ${ }^{2}$

These seven factors, argues the World Bank, have put many old-age systems in serious financial trouble.

\footnotetext{
2 Estelle James, Averting the Old Age Crisis, Ageing International, July 1995 at 15-22. This article by James summarizes the 1994 World Bank report Averting the Old Ages Crisis.
} 


\section{Privatization proposed}

This conclusion led the World Bank to suggest a multipillar system with separate administrative and financing mechanisms for redistribution (welfare) and savings. First, instead of the traditional social security system, a publicly managed tax-financed pillar would have the primary goal of reducing poverty among the old through means-tested payments. Second, a mandatory but privately managed, funded individual-equity pillar would have the primary responsibility for investing the savings of individuals. The third pillar would consist of voluntary savings-annuity plans for people who wish to save even more for additional income in retirement. Basically, the multipillar proposal is an ambitious plan for privatizing social security.

\section{Privatization issues}

Privatizing social security means that the primary responsibility for retirement income would shift from the taxpayer and government to workers who would be required to save and to invest the savings in the private sector. A privatized system of individual saving and investment has a number of attractive features, but it also carries with it potential problems. Certain key issues, as discussed below, would need to be addressed before privatization could be seriously considered.

Are individuals in general able and eager to manage their own investments? What opportunity cost will be incurred if they must do so? If, instead, money-managers do it for them, how much will such services cost? What should the role of society be in cases of investment failure ? 3

The privatization debate essentially revolves around the advantages and disadvantages of defined benefit plans with pay-as-you-go financing, as compared to defined contribution plans. In general, social security is a defined benefit plan; it guarantees a benefit based on a predetermined formula. Privatized plans are defined contribution plans; they do not guarantee a specified level of retirement income. The level of income during retirement depends on the amount saved and the pre-retirement investment earnings, taking into account actuarial and financial circumstances at retirement when the total accumulation is converted into a legal contract for income payments. This issue is obviously important because it concerns the adequacy of retirement income.

Most advocates of privatizing social security assume that the interest rates earned by the investable funds will be high. However, the financial market, like all other markets, has two sides-supply and demand. Increasing savings will increase the supply of investable funds. Unless the demand for investable funds increases commensurately, market forces will lower the rate of interest. While rates of investment return may be high for some periods of time in a country where privatization is implemented, it cannot be assumed that the rates of return will be consistently high over the long run.

${ }^{3}$ Proposals for Alternative Investment of the Social Security Trust Fund Reserves: Hearing Before the Subcomm. on Social Security of the House of Representatives, Comm. on Ways and Means, 103rd Cong., 2d Sess., Ser. 103-106, at 98-108 (1995) (statement of Yung-Ping Chen on key issues of privatizing Social Security). 
Social security generally provides retirement, survivorship, and disability benefits in a single package. Typically, advocates of privatization point to higher retirement benefits which they contend could be offered by private investments. They are generally silent, however, about the benefits for survivors and for the disabled. Some proponents of privatization do try to provide for survivorship and disability benefits with a life insurance policy and disability income policy. But they frequently illustrate the costs for providing these benefits by quoting the premiums private insurance carriers charge for those policies, which are lower due to their underwriting requirements. Moreover, not all occupations are insurable for disability by private insurance, and among those that are insurable, premiums for the same benefits can differ considerably by occupational category.

In addition, when part or all of the taxes that go into social security are converted into private investments, the feature of social adequacy under social security (i.e., the transfer to low-income earners) will be reduced or eliminated. Unless society can tolerate some of its citizens living in squalor or destitution, the cost of welfare for people who have not been able to save enough or who have failed in their investments must be paid. This income redistribution will be principally from higher-income people, through the first pillar (taxation), thus reducing the higher returns which the well-to-do are expected to receive through the second or third pillar.

Finally, a serious question about the transition remains. How do we move from the current system of Social Security to the world envisioned by the privatizers? Because Social Security is financed on an essentially pay-as-you-go basis under which current taxes are used to pay current benefits, how are benefits to be paid when some or all of the taxes are redirected to privatized accounts? The costs involved in the transition to the new system need to be paid. Are workers now and those in the foreseeable future expected (1) to help pay for the benefits promised to current beneficiaries and those in the transition period and (2) also to contribute to privatized accounts for their own retirements?

While the World Bank report does not discuss these issues, it does conceed that in order for the system of three pillars to work, countries must have at least rudimentary capital markets, considerable government regulation is essential to avoid investments that are overly risky or to weed out managers who commit fraud, and a public system or pillar is needed to provide a social safety net for people whose lifetime earnings are low or whose investments fail. The World Bank should be commended for issuing these warnings. Nevertheless, it should be noted that capital markets need to be more than just "rudimentary," and sound government regulation takes time to develop and is costly to maintain. Conditions conducive to privatized plans for saving and investment do not yet exist in many countries.

\section{Social security's inherent problems?}

On the other hand, there is nothing basically wrong with the approach of social insurance that undergirds social security. Most of the seven factors which, according to the World Bank have threatened so many publicly funded old-age security plans, are attributable to plan designers and policy makers. They are not intrinsic to the social insurance model of social security. "High payroll-tax rates" are largely required for high promised benefit payments, but such promises are not preordained. "Evasion and labor-market distortions" come from ineffective enforcement of the law and poor plan design; they are not 
an inherent part of social security. While "early retirement" is available to workers at relatively young ages without a reduction in benefits under many systems; it is not a sine qua non of social security. If it is agreed that there is "misallocation of public resources," it could be corrected, and it is certainly not an essential aspect of social security. The issue of "lost opportunities to increase savings" is still controversial. "Perverse redistribution to upperincome groups" is certainly not a predestined outcome of social security. "Positive lifetime transfers to early cohorts and lower returns to later cohorts," again, result mostly from plan design or changing demographics and are not an innate feature of social insurance. In short, all these problems are not inseparable elements of social insurance.

\section{Reasons for social security's financial problems}

Despite these disclaimers, it must be acknowledged that the costs of social security everywhere have been rising and, if allowed to persist, will rise to even greater heights and possibly to financially untenable levels.

Four major factors seem to be at work in this phenomenon. The first two-growth rate of the population and that of the economy - relate to the workings of a traditional pay-asyou-go approach to social insurance programs - an intergenerational transfer model in which the working generation finances benefits for the retired generation. This system works well as long as the population and the economy are growing sufficiently so that, over the long run, the taxes paid by workers and their employers rise faster than, or at least keep pace with, benefits paid out. In many countries, however, social security has become a focus of intense criticism and debate because of sluggish economic growth coupled with population aging.

A third factor in social security's escalating costs is the eternal temptation of politicians to promise ever-increasing types and levels of benefits. Finally, many social programs, including social security, are begun when economic and/or demographic conditions are favorable, without regard for the long run. Over time, as economic and demographic conditions change, an imbalance between the program's income and what it spends can develop. If government fails to act or acts too slowly to correct the imbalance, the program deteriorates.

The way to rectify this situation is not to dismantle social security and replace it with a privatized plan, as some have proposed. There is nothing intrinsically wrong with the social insurance model, as previously pointed out. A better policy choice would be to redesign social security, making it as self-adjusting and self-sustaining as possible. A sustainable policy is one that adapts automatically to changing conditions.

\section{Redesigning social security}

The U.S. social security program may be used to illustrate how an existing system may be redesigned to deal with the economic and demographic causes of its financial problems?

A wage-based system. A major economic cause of the program's financial instability arises from the fact that its income depends on the payroll tax, which is based on wages, and its outgo reflects prices of goods and services, which determine the cost-of-living adjustments. The difference between the annual rate of change in the average wage and the annual rate of change in the Consumer Price Index (CPI) is known as the real-wage differential. Variations in this differential can have a major impact on costs of the social security system. 
The benefit structure can be made more nearly self-sustaining if the law provides that the automatic benefit increases will be based on the increase in the nationwide average wage rate minus some fixed percentage point ${ }^{4}$ The fixed percentage point should be chosen according to what the real-wage differential is expected to be over the long run. This procedure will result in a benefit computation based solely on one element - wages - thereby eliminating the instability brought about by the wage level and the price level changing at rates that diverge from those assumed in the actuarial model.

Basing social security's income and its outgo on wages would substantially stabilize its financing position insofar as variations in economic conditions pertaining to wages and prices are concerned. Aside from providing financial stability, a wage-based system will improve the relative equity between workers and retirees. Thus, if economic conditions are very favorable, beneficiaries would see their benefits increase, reflecting some of the general increase in the standard of living based on wage increases, which will exceed the CPI growth. Conversely, if economic conditions are unfavorable, benefit increases will be less than rises in the CPI so that beneficiaries would share in the general misfortune of the working population.

This proposal would not solve any financial problems arising from other economic elements, such as the unemployment rate. Nonetheless, the real-wage differential is by far the most important economic element in the long-range financing of the social security program. ${ }^{5}$

A formula-based normal retirement age. The demographic cause of social security's financial problems results fron the demographic load, i.e., the ratio of beneficiaries to workers/taxpayers. The U.S. demographic loas is projected to increase by 58 percent by the year 2030. Preventing social security costs as a percentage of taxable payroll from increasing significantly will require addressing the rapid growth in the number of beneficiaries relative to the number of workers. Raising the normal retirement age is one way to moderate the rise in total benefit payments.

One way to reset the normal retirement age is to keep constant the ratio between (a) retirement-life expectancy and (b) potential working life, thus establishing an equivalent retirement age. ${ }^{6}$ The former, (a), refers to average expected years of life at the normal retirement age. The latter, (b), is defined by the number of years between age 20 and the normal retirement age. Suppose the ratio between (a) and (b) is 1 to 3 in year $x$ (for example, 1940). Assume that the average retirement-life expectancy increases by one year by a future year $y$ (for example, 1990). If the ratio between (a) and (b) is kept constant (the same in both years), then a one-year extension of life will result in an increase of roughly 3 months of retirement and roughly 9 months of work in year $y$.

However, increasing the normal retirement age is a contentious issue, igniting spirited debate. To avoid the inaction that often comes with such controversy, it might be preferable to reset the normal retirement age periodically (say, once every 10 years) on an automatic

\footnotetext{
${ }^{4}$ Staff Memoranda Nos. 16, $19 \& 20$ from Robert J. Myers of the National Comm. on Soc. Sec. Reform (1982).

${ }^{5}$ Staff Memoranda Nos. 16, 19 \& 26 from Robert J. Myers of the National Comm. on Soc. Sec. Reform (1982).

6 Yung-Ping Chen, Making Assets Out of Tomorrow's Elderly, 27 Gerontologist 410-16 (1987); F. R. Bayo \& J. Faber, Social Sec. Admin. U.S. Dept. of Health \& Human Services, Pub. No. 11-11500.6 Equivalent Retirement Ages : 1940-2050 (Actuarial Note No. 105) (1981).
} 
basis according to national statistics on average life expectancy at the current normal retirement age. If an automatic extension of the normal retirement age (based on the equivalent retirement age concept) can be part of the law, then the cost of social security attributable to increasing longevity could be systematically controlled.

\section{The fourth pillar and income security}

A three-legged stool, comprising social security, occupational pensions, and individual savings, has been the metaphor widely used to symbolize the sources of income to older people in the United States. The significant role of social security is evident from the following tabulations. Although pensions and income from assets are meant to be important supplements to it, in fact, employment is another major source of income.

According to the latest available statistics, the propositions of those aged 65 and over who received income from these major sources in 1994 were : 7

- Social Security $91 \%$

- Asset Income 67\%

- Occupational Pensions 45\% (Private Pensions 30\%)

- Employment Income $21 \%$

The above percentages refer to the magnitudes of older people who received income from different sources. Those sources of income did not contribute equally to the total income of the elderly, however. The relative shares of those sources in the total income in 1994 were : ${ }^{7}$

- Social Security $42 \%$

- Asset Income $18 \%$

- Occupational Pensions $19 \%$ (Private Pensions 10\%)

- Employment Income $18 \%$

These sources of income essentially reflect the "four pillars" approach. ${ }^{8}$ The first is the compulsory state pension usually known as social security. The second is the supplementary employer pension. The third is income from individual savings. And the fourth, the option open to older people to work part-time with a partial pension to augment the income from the other three sources.

\footnotetext{
${ }^{7}$ Grad, S. (1996), Income of the Population 55 or Older, 1994 (Social Security Administration, Washington, D.C., SSA Publication no. 13-11871), Jan, p. 1 and p. 109.

${ }^{8}$ Giarini, O. and W.R. Stahel (1993), The Limits to Certainty, Kluwer Academic Publishers, Dordrecht. Reday-Mulvey, G. (1990), "Work and Retirement; Future Prospects for the Baby-boom Generation", The Geneva Papers on Risk and Insurance, no. 55, pp. 100-114.
} 
It is worth emphasizing, however, that income from the fourth pillar is substantively different from the employment income cited above as a source in the case of the United States. The fourth pillar concept envisions income from part-time employment with partial pensions, while employment income in the U.S. comes from both full-time and part-time work, with social security benefits withheld from some people for earnings exceeding a certain level per year, but not under a system of part-time employment with partial pensions.

Employment income. Employment as a source of income for the elderly in the U.S. has clearly declined during the past three decades. Whereas $36 \%$ of the older population had earnings in 1962 , only $21 \%$ of them did in $1994 .{ }^{9}$ While earnings represented $28 \%$ of total income of all older persons in 1962 , they accounted for only $18 \%$ of their total income in $1994 .{ }^{10}$

Gradual retirement with partial pensions. Therefore, a third element in the redesign of the U.S. social security program is to institute a system of partial pensions for partial retirement, thus coordinating the policy on social security with the policy on older-worker employment. At present, workers who want to retire gradually with an interim period of part-time employment confront a number of obstacles. Occupational pension plans rarely allow a beneficiary to continue working for the same firm. If a beneficiary finds employment, social security lowers benefits for those who earn beyond an allowable amount through the earnings test - a considerable work disincentive to persons with earnings beyond the annual exempt amount.

Slow economic growth and population aging have raised concerns about the ability of society to finance pensions (public and private) and health services for the elderly. In addition, projections of a slower growth in the working-age population have led to concerns about labor force shortages in the future. One way to mitigate these problems is to prolong the working life of older people. Postponing the normal retirement age, coupled with a desire on the part of older people to work part-time (as expressed in practice and in opinion surveys in many countries) would seem to provide a recipe for gradual retirement. Partial pensions for partial retirement may be a practicable approach.

People work for a variety of reasons, and these reasons change as workers grow older. Many say that they are willing and able to work longer than they currently do, especially on a part-time basis. At age 63 and over, for example, "enjoying work" is the most frequently cited reason for working, followed by feeling useful, being productive, work as obligation, and maintaining health insurance. Significantly, the need for income is mentioned least often. ${ }^{11}$

In order to implement gradual retirement with partial pensions, institutional and attitudinal changes are needed. If we assume the willingness of older workers to remain in the labor market, occupational pension and social security provisions that offer retirement incentives (or work disincentives) should be eliminated. For example, the delayed retirement credit under social security should be made actuarially fair immediately, not waiting

${ }^{9}$ SSA (1994), Income of the Aged Chartbook, 1992, Social Security Administration, Washington, D.C., SSA Publication no. 13-11727, December, p. 20 and Grad (1996), p. 1.

10 SSA (1994), Income of the Aged Chartbook, 1992, Social Security Administration, Washington, D.C., SSA Publication no. 13-11727, December, p. 22 and Grad (1996), p. 109.

11 U.S. Dept. of Labor, Older Worker Task Force: Key Policy Issues for the Future (1989). 
until the year 2009 as provided under current law. ${ }^{12}$ In order to accommodate workers in general and older workers in particular, flexible work schedules and training/retraining programs should be more widely and systematically available. The types of available jobs are also important. If, indeed, part-time jobs are what are needed to implement partial pensions, then the willingness of employers to create such opportunities and the cooperation of full-time workers to support them will be necessary.

To promote gradual retirement by means of partial pensions would require a major change in social security and occupational pension programs. However, to implement gradual retirement in the United States through a system of part-time work with partial pensions will have many salubrious effects, including easing the concern over the extension of the normal retirement age. Gradual retirement via part-time jobs potentially is compatible with health promotion, caregiving and volunteering, self-actualization activities, not to mention the benefits to society through more production and lower pension costs without necessarily competing against younger people for full-time employment.

\section{Conclusion}

Although a privatized plan for individual saving and investment has attractive features, some key questions about privatization await satisfactory answers. On the other hand, the design and policy maladies that undermine social security should and can be corrected. With its costs controlled by better plan designs and sensible policies, a redesigned social security program would become self-sustaining and financially stable. With a stable social security program as a foundation for a basic level of retirement income, other means of income support, including income from part-time employment, can then be used as supplements to it.

12 The delayed retirement credit (DRC) is designed to compensate workers for not receiving benefits when they defer retirement. In other words, DRC increases their future benefits. The DRC rate, under existing law, is 4.5 percent for persons born in 1929 or 1930. This is scheduled to rise to 8 percent for those born in 1943 or later. When DRC is at the rate of 8 percent, the compensation will become actuarially fair, in the sense that what one does not receive today, one will receive tomorrow. However, for all those born before 1943, thus attaining the normal retirement age before the year 2009, the compensation is actuarially unfair, because future increases in benefits are less in present value terms than the current reductions in benefits. 